\title{
Compatibility of azoxystrobin and cyproconazole on plant growth- promoting microorganisms
}

\author{
Weslany Silva Rocha1, Mara Caroline Alves da Silva², Gilberto Coutinho Machado Filho², \\ Mauro Gomes dos Santos², Aloísio Freitas Chagas Júnior², Manoel Mota dos Santos² \\ ${ }^{1}$ Universidade Federal do Tocantins, Campus Palmas, Palmas, Tocantins, Brasil. E-mail: weslanythd@ hotmail.com \\ ${ }^{2}$ Universidade Federal do Tocantins, Campus Gurupi, Gurupi, Tocantins, Brasil. E-mail: maraagro22@yahoo.com.br, \\ coutinhoagro@hotmail.com, maurogomes@uft.edu.br, chagasjraf@mail.uft.edu.br, santosmm@mail.uft.edu.br
}

Received: 15/07/2020; Accepted: 20/10/2020.

\begin{abstract}
Avoiding the toxicity effect of chemical fungicides on rhizobacteria is a sustainable alternative for agroecosystem management. Rhizobacteria, whose bioprotective and plant growth-promoter potential have been reported in the literature, lack studies on their performance in integrated management with pesticides. Thus, this study aimed to evaluate the effects of azoxystrobin + cyproconazole on the growth of Bacillus subtilis, Streptomyces seoulensis, and Bradyrhizobium japonicum. Three independent experiments were set up, i.e., one for each microorganism, and carried out in a completely randomized design in a factorial scheme $(3 \times 6)$, with three doses (recommended by the manufacturer, half, and twice) and six periods of evaluations (48, 96, 144, 192, 240, and 288 hours), with three replications. Growth inhibition rings were evaluated. Azoxystrobin + cyproconazole at all tested doses is compatible with $B$. subtilis. The use of azoxystrobin + cyproconazole affected the growth of B. japonicum and S. seoulensis, which were sensitive to all its doses until 288 hours after inoculation.
\end{abstract}

Keywords: fungicide, doses, toxicity, rhizobacteria.

\section{Compatibilidade de azoxistrobina e ciproconazol sobre microrganismos promotores de crescimento vegetal}

\section{RESUMO}

Evitar o efeito da toxicidade dos fungicidas químicos sobre as rizobactérias é uma alternativa sustentável para o manejo do agroecossistema. As rizobactérias, cujo potencial bioprotetor e promotor de crescimento vegetal vêm sendo reportado na literatura, carecem de estudos sobre sua atuação em manejos integrados com defensivos. Desta forma, objetivou-se avaliar os efeitos de Azoxistrobina + Ciproconazol no crescimento de Bacillus subtilis, Streptomyces seoulensis e Bradyrhizobium japonicum. Para isso, instalaram-se três experimentos independentes, ou seja, um para cada microrganismo, realizados em delineamento inteiramente casualizado sob esquema fatorial ( 3 x 6), sendo três doses (recomendada pelo fabricante, a metade e o dobro) e seis períodos de avaliações (48, 96, 144, 192, 240 e 288 horas), com três repetições cada. Avaliaram-se os halos de inibição de crescimento. Azoxistrobina + ciproconazol em todas as doses testadas é compatível com o B. subtilis. O uso Azoxistrobina + Ciproconazol afetou o crescimento de B. japonicum e de $S$. seoulensis, sendo sensíveis a todas as doses deste fungicida até as 288 horas após a inoculação.

Palavras-chave: fungicida, doses, toxidez, rizobactérias. 


\section{Introduction}

Plant growth-promoting (PGP) microorganisms are organisms that colonize the rhizosphere and rhizoplane and improve plant growth when artificially inoculated into seeds or soil. PGP microorganisms can promote plant growth by direct stimulation, such as iron chelation, phosphate solubilization, nitrogen fixation, and phytohormone production (Hao et al., 2011; Panhwar et al., 2012), or indirect stimulation, such as plant pathogen suppression and induction of resistance in host plants against pathogens (Qiao et al., 2014; Sousa and Olivares, 2016). According to Souza et al. (2015), the mechanisms by which bacteria can influence plant growth differ between species and strains, as there is typically no single mechanism to promote plant growth.

Plant growth-promoting bacteria (BPCP), such as rhizobia, promote symbiosis and, consequently, biological nitrogen fixation (BNF) (Franche et al., 2009). On the other hand, B. subtilis may be able to increase nitrogen fixation, solubilize nutrients, synthesize phytohormones, and improve soil conditions, in addition to the indirect benefits of suppressing this environment against harmful microorganisms (Manjula and Podile, 2005). The growth-promoting effects of Streptomyces sp. related to plant interactions can be divided into biofertilization, biostimulation, and bioprotection (Saharan and Nehra, 2011). Thus, all these microorganisms can be used in agriculture to promote plant growth or control agricultural diseases and pests. However, for this to be possible, these microorganisms must not be affected by other practices carried out in current agriculture, such as the use of chemicals such as fungicides.

Santos et al. (2018) evaluated the compatibility of seed treatment and in vitro rhizobia and observed that the strain INPA 0311B (B. japonicum) was not affected when treated with thiophanate methyl and fluazinam. In this case, the growth of colonies exposed to the different concentrations of the products $(2.54$ to $10.18 \mathrm{~mL} 100$ $\mathrm{kg}^{-1}$ seeds) was similar to the control treatment at all observed hours.

Likewise, the results obtained by Palazzini et al. (2018) indicate the possibility of using B. velezensis RC 218 and Streptomyces sp. RC 87B in combination with triazole-based fungicides at lower doses as part of integrated management of Fusarium head blight (FHB) in wheat.

In this sense, there is a lack of scientific studies on the effect of fungicides associated with these plant growthpromoting bacteria, which does not allow studies of comparison between the behaviors of microorganisms with this formulation. In addition, most of the existing studies are related to insecticides.
The knowledge of the compatibility of biocontrol agents with other components of production systems is necessary to develop viable management strategies (Valarmathi et al., 2013).

Moreover, compatibility tests of chemicals are important for understanding their effects on in vitro microorganisms since they expose the control agents to all possible negative or positive effects that they may undergo when applied in combination, mainly in cases when a mixture is performed (Rossi-Zalaf et al., 2008).

However, certain active ingredients found in fungicides have been showing deleterious effects on the activity of plant growth-promoting bacteria, as is the case in Bradyrhizobium spp. (Campo et al., 2009; Pereira et al., 2010).

Halfeld-Vieira and Santos (2018) evaluated the compatibility between biological bacterial actives and agrochemicals used in the production of sugarcane seedlings, such as the product Priori Xtra, in the maximum concentration recommended by the manufacturer. They observed that $B$. aryabhattai remained viable when exposed to Priori Xtra for a period of 1 hour, but with a reduction in cell viability compared to the control.

Therefore, this study aimed to evaluate the effects of a commercial product based on azoxystrobin + cyproconazole on the growth of B. subtilis, S. seoulensis, and $B$. japonicum as a function of the evaluation periods.

\section{Material and Methods}

The experiments were carried out at the Laboratory of Soil Microbiology at the University Campus of the Federal University of Tocantins, located in Gurupi, state of Tocantins, Brazil, at the geographic coordinates $11^{\circ} 46^{\prime} 25.9^{\prime \prime} \mathrm{S}$ and $49^{\circ} 03^{\prime} 06^{\prime \prime} \mathrm{W}$ and altitude of $293 \mathrm{~m}$.

The tested isolates were obtained at the Laboratory of Applied Agromicrobiology and Biotechnology of PPGPV/UFT of the Federal University of Tocantins and identified by sequencing the $16 \mathrm{~S}$ gene. The isolates consisted of B. subtilis strain Bs10, S. seoulensis, and B. japonicum (INPA 03-11B). Three independent experiments were installed, that is, one for each microorganism. Each experiment was carried out in a completely randomized design, considering in a factorial scheme $(3 \times 6)$. The first factor consisted of three doses of the fungicide Priori Xtra (azoxystrobin + cyproconazole), i.e., the dose recommended by the manufacturer $(300 \mathrm{~mL}$ commercial product ha $\mathrm{h}^{-1}$ for soybean), half, and twice the recommended dose, while the second factor consisted of six evaluation periods (48, 96, 144, 192, 240, and 288 hours after inoculation), with three replications. The treatments were: 


\begin{tabular}{ll}
\hline Experiment 1 & \\
\hline T1 & B. subtilis + half the recommended dose of the commercial product \\
T2 & B. subtilis + recommended dose of the commercial product \\
T3 & B. subtilis + twice the recommended dose of the commercial product \\
\hline Experiment 2 & \\
\hline T1 & S. seoulensis + half the recommended dose of the commercial product \\
T2 & S. seoulensis + recommended dose of the commercial product \\
T3 & S. seoulensis + twice the recommended dose of the commercial product \\
\hline Experiment 3 & \\
\hline T1 & B. japonicum + half the recommended dose of the commercial product \\
T2 & B. japonicum + recommended dose of the commercial product \\
T3 & B. japonicum + twice the recommended dose of the commercial product \\
\hline
\end{tabular}

Initially, the microorganisms were inoculated into a Petri dish (90 $\mathrm{mm}$ in diameter) using the streak plate technique on the surface of the culture medium using a platinum loop along the entire length of the plate. After streaking, the compatibility analysis was carried out by the agar diffusion test, in which three $0.10-\mathrm{cm}$ diameter white filter paper discs, previously soaked in the fungicide solutions with sterile distilled water (doses), and one disc soaked in sterile distilled water, were placed equidistantly on the sides of each plate, according to the methodology of Bauer et al. (1966). The plates were then incubated in a growth chamber at a temperature of $28 \pm$ $1{ }^{\circ} \mathrm{C}$ and a 12-hour photoperiod.

The evaluated parameter was the formation of an inhibition ring around the filter paper disc every 48 hours. The inhibition rings were measured in two orthogonal directions by a digital caliper ( $\mathrm{mm}$ ) and the obtained values were averaged. The behavior of the fungicide relative to microorganisms was defined as incompatible when it promoted the formation of an inhibition ring around the paper disc compared to the control and as compatible when it promoted no ring formation. Moreover, the behavior was defined as partially compatible, according to the methodology proposed by Silva et al. (2006), when the fungicide allowed the formation of an inhibition ring around the paper discs, but with the presence of colony-forming units (CFU) and/or spores.

The data were subjected to analysis of variance by the F-test using the statistical program SISVAR (Ferreira, 2019). The regression test was also applied for the source of variation doses and the selection of the models was based on the significance of betas and the highest coefficient of determination $\left(\mathrm{R}^{2}\right)$ using the software SigmaPlot ${ }^{\circledR}$ version 10.0.

\section{Results and Discussion}

The analysis of variance by the F-test showed an interaction $(p<0.01)$ between the doses of azoxystrobin + cyproconazole and periods of evaluation. The effect of doses of azoxystrobin + cyproconazole on the inhibition ring of the isolated microorganisms demonstrated varied responses, similar to other studies (Pereira et al., 2010; Mohiddin and Khan, 2013; Marks et al., 2013; Constantinescu et al., 2014).

The applied doses did not fit the regression models, thus $\mathrm{y}=$ mean (0.0) (Figure 1). B. subtilis Bs10 had no sensitivity to the in vitro in azoxystrobin + cyproconazole for the three tested doses, as inhibition rings were not formed over the evaluated hours. Therefore, the product was compatible, evidencing the absence of negative response of these colonies to the fungicide. The active ingredients strobilurin (azoxystrobin) and triazole (cyproconazole) have two different modes of action, the first belonging to the quinone outside inhibitors (QoI) group (interfering with ATP production) and the latter belonging to the ergosterol biosynthesis inhibitors (EBI) group (FRAC-Brasil, 2020). The species B. subtilis was not affected by these components because it uses different pathways for its metabolism.

According to Blencke et al. (2003), B. subtilis catabolizes glucose through the glycolytic and pentose phosphate pathways. The formed pyruvate can be oxidized to acetyl-coenzyme A (acetyl-CoA) or regenerate $\mathrm{NAD}^{+}$in fermentation. Similarly, acetyl-CoA can be completely oxidized in the Krebs cycle or the thioester energy can be directed to phosphorylation at the substrate level to form acetate. Therefore, the hypothesis is that B. subtilis Bs10 has used this alternative pathway to catabolize glucose or directed energy towards phosphorylation. It is even one of the resistance mechanisms used by fungi to survive the action of this fungicide, but the resistance mechanisms are not yet fully understood (FRAC-Brasil, 2020).

Silva et al. (2006) concluded that the effect of fungicides varies according to the evaluation technique, the stage/phase of the pathogen life cycle (cell and spore), and concentrations. Several studies have reported the compatibility of biocontrol agents with systemic fungicides, such as azoxystrobin. Sendhilvel et al. (2004) studied the compatibility of azoxystrobin $25 \mathrm{SC}$ at 125 , 150,200 , and $250 \mathrm{ppm}$ with biological control agents and found that the bacterial biocontrol agents ( $P$. fluorescens and $B$. subtilis) were not affected by azoxystrobin, which is perfectly compatible with bacterial biocontrol agents. 
Similarly, Anand et al. (2007) studied the compatibility of azoxystrobin $23 \mathrm{SC}$ with biological control agents using $P$. fluorescens and B. subtilisSVPR4 under in vitro conditions and reported that the growth of these microorganisms was not affected even at higher concentrations ( 5 to $300 \mathrm{ppm}$ ). It indicates that this microorganism was not affected by this active ingredient even at higher concentrations than those used in this study.

A quadratic model was adjusted for both the recommended dose and the curve of twice the recommended dose by the regression test, with $\mathrm{R}^{2}$ of 83 and $92 \%$, respectively. However, the regression curve could not be adjusted for half the recommended dose and, therefore, $\mathrm{y}=$ mean $(28.33 \mathrm{~mm})$. The largest diameter of the inhibition ring $(36.1 \mathrm{~mm})$ for the curve of the recommended dose was observed at 96 hours after inoculation and the smallest ring occurred at 288 hours, with $23.1 \mathrm{~mm}$. The curve that represents twice the recommended dose showed an inhibition ring of $36 \mathrm{~mm}$ at the beginning of the evaluation (48 hours). Thereafter, the diameter of the inhibition ring was reduced by up to $18.9 \mathrm{~mm}$ until the end of the evaluation period at 288 hours (Figure 2). S. seoulensis demonstrated sensitivity to the azoxystrobin + cyproconazole doses in the in vitro test, especially at the first hours of contact, being then adapted to the medium with the product, producing inhibition rings that reached $36.1 \mathrm{~mm}$ until 96 hours after inoculation.

Possibly, some physicochemical characteristics of the active ingredient or even another inert component have changed the ability of $S$. seoulensis cells to survive during the experiment, which may be related to the $\mathrm{pH}$ or salinity of the commercial product. The data show the possibility of using this fungicide at lower doses, which can be combined with this biocontrol agent. Thus, it was defined as partially compatible.

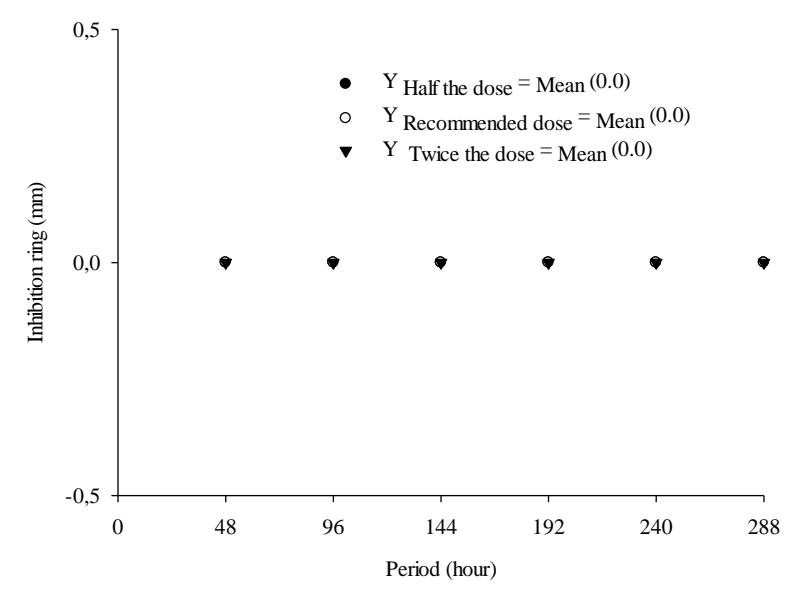

Figure 1. Effect of doses of azoxystrobin + cyproconazole on the growth inhibition rings of $B$. subtilis Bs10 in culture medium as a function of the periods of evaluation, Gurupi, TO, Brazil, 2017.
These results are similar to those obtained by Palazzini et al. (2018), who evaluated the tolerance of biocontrol agents, including Streptomyces sp. RC 87B in combination with triazole-based fungicides, such as prothioconazole, tebuconazole, and metconazole under in vitro conditions. The authors demonstrated that Streptomyces sp. RC 87B showed high tolerance to the growth with prothioconazole at a concentration of up to 10 $\mu \mathrm{g} \mathrm{mL}^{-1}$ and complete growth inhibition at concentrations of $20 \mu \mathrm{g} \mathrm{mL} \mathrm{mL}^{-1}$ for metconazole, $40 \mu \mathrm{g} \mathrm{mL} \mathrm{mL}^{-1}$ for tebuconazole, and $80 \mu \mathrm{g} \mathrm{mL}^{-1}$ for prothioconazole. These results reflect the possibility of using fungicides at low doses associated with biocontrol agents.

No adjustments in the regression curves were performed. However, azoxystrobin + cyproconazole presented toxicity to the isolate $B$. japonicum (strain INPA 0311B) at all doses, mainly up to 96 hours after inoculation, with an inhibition ring of approximately 32 $\mathrm{mm}$ (Figure 3 ). This product was defined as partially compatible for rhizobia despite the inhibition rings, as CFU could be observed at the inhibition area at all concentrations. The product is recommended to control fungi, but the presence of toxic components also for bacteria possibly inhibited their growth. One of its components is triazoles, which cause the rupture of the cell membrane and, consequently, leakage of ionic solutes (FRAC-Brasil, 2020), which may have occurred in this study.

The results obtained in this study confirm the toxicological and environmental classification of the Ministry of Agriculture, Livestock, and Supply of Brazil (Agrofit, 2019), in which the azoxystrobin + cyproconazole-based fungicide is described as Category 4 , that is, low toxic and classification II for the potential of environmental hazard II, that is, very dangerous to the environment. Thus, the product presents a risk of damage to the soil microbiota.

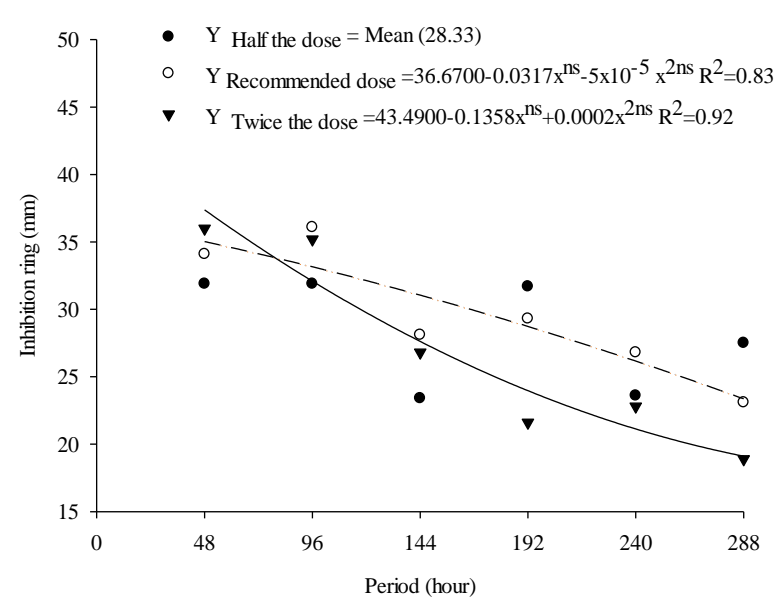

Figure 2. Effect of doses of azoxystrobin + cyproconazole on the growth inhibition rings of $S$. seoulensis in culture medium as a function of the periods of evaluation, Gurupi, TO, Brazil, 2017. 


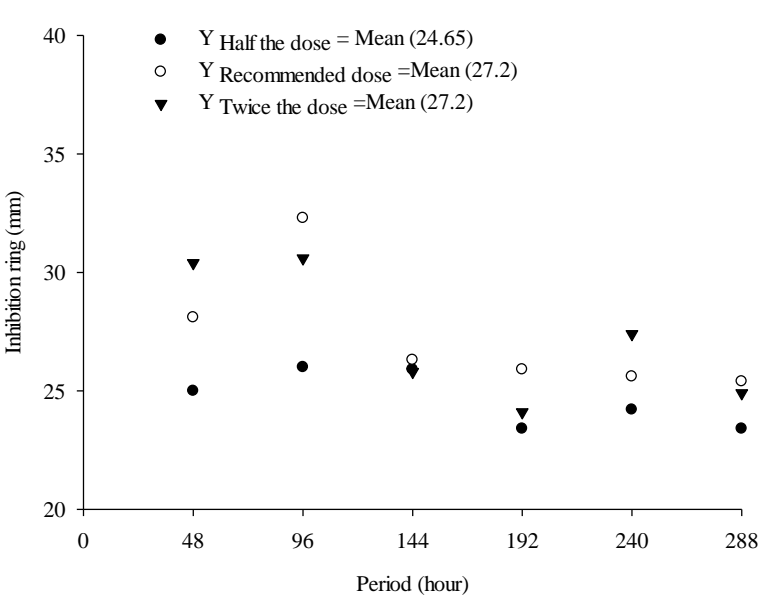

Figure 3. Effect of doses of azoxystrobin + cyproconazole on the growth inhibition rings of B. japonicum (INPA 0311B) in culture medium as a function of the periods of evaluation, Gurupi, TO, Brazil, 2017.

\section{Conclusions}

The association of azoxystrobin + cyproconazole at all tested doses was compatible with the isolate $B$. subtilis.

The use of azoxystrobin + cyproconazole affected the growth of B. japonicum and $S$. seoulensis, being sensitive to all doses of this fungicide until 288 hours after inoculation.

\section{Acknowledgments}

The authors would like to thank the National Council for Scientific and Technological Development (CNPq/UFT) and the Coordination for the Improvement of Higher Education Personnel (Capes) for the technical support in the development of this research.

\section{Bibliographic References}

AGROFIT - Sistema de agrotóxicos fitossanitários, 2019. Consulta de Produtos Formulados. Ministério da Agricultura, Pecuária e Abastecimento - Coordenação-Geral de Agrotóxicos e Afins/DFIA/SDA http://agrofit.agricultura.gov.br/agrofit_cons/!ap_produto_for m_detalhe_cons?p_id_produto_formulado_tecnico $=7840 \& p \_t$ ipo_janela=NEW (acessado 14 de julho de 2020).

Anand, T., Prakasam, V., Chandrasekaran, A., Samiyappan, R., Karthikeyan, G., Saravanan, A., 2007. Compatibility of azoxystrobin (Amistar 25 SC) with biocontrol agents. Pestology, 31(5), 21-24.

Bauer, A.W., Kirby, W.M., Sherris, J.C., Turck, M., 1966. Antibiotic susceptibility testing by a standardized single disk method. American Journal of Clinical Pathology, 45(4), 493496.

Blencke, H., Homuth, G., Ludwig, H., Mader, U., Hecker, M., Stulke, J., 2003. Transcriptional profiling of gene expression IN response to glucose in Bacillus subtilis: regulation of the central metabolic pathways. Metabolic Engineering, 5(2), 462-468. DOI: 10.1016/s1096-7176(03)00009-0.

Campo, R.J., Araujo, R.S., Hungria, M., 2009. Nitrogen fixation with the soybean crop in Brazil: compatibility between seed treatment with fungicides and bradyrhizobial inoculants. Symbiosis, 48(1), 154-163. DOI: 10.1007/BF03179994.

Constantinescu, F., Sicuia, O-A., Fatu, C., Dinu, M.M., Andrei, A-M., Mincea, C., 2014. In vitro compatibility between chemical and biological products used for seed treatment. Scientific Papers. Series A. Agronomy, 57(1), 146-151.

Ferreira, D.F., 2019. Sisvar: a computer analysis system to fixed effects split plot type designs. Revista Brasileira de Biometria, 37(4), 529-535. DOI: 10.28951/rbb.v37i4.450.

FRAC-Brasil, 2020. Comitê de Ação a Resistência a Fungicidas. Modo de Ação de Fungicidas. http://www.fracbr.org/modo-de-acao (acessado 08 de julho de 2020).

Franche, C., Lindström, K., Elmerich, C., 2009. Nitrogenfixing bacteria associated with leguminous and non-leguminous plants. Plant and Soil, 321(1-2), 35-59. DOI: 10.1007 / s11104008-9833-8.

Halfeld-Vieira, B.A., Santos, M.S., 2018. Compatibilidade entre ativos biológicos bacterianos e agroquímicos utilizados na produção de mudas de cana-de-açúcar. Jaguariúna, Embrapa Meio Ambiente, 27 p. (Boletim de Pesquisa e Desenvolvimento, 77).

Hao, D., Gao, P., Liu, P., Zhao, J., Wang, Y., Yang, W., Lu, Y., Shi, T., Zhang, X., 2011. AC3-33, a new secretory protein, inhibits the transcriptional activity of Elk1 via ERK. Molecular Biology Reports, 38(1), 1375-1382. DOI: 10.1007/s11033-0100240-x.

Manjula, K., Podile, A.R., 2005. Increase in seedling emergence and dry weight of pigeon pea in the field with chitinsupplemented formulations of Bacillus subtilis AF 1. World Journal of Microbiology \& Biotechnology, 21(6), 1057-1062. DOI: $10.1007 / \mathrm{s} 11274-004-8148-\mathrm{z}$.

Marks, B.B., Bangel, E.V., Tedesco, V., Silva, S.L.C., Ferreira, S.B., Vargas, R., Silva, G.M., 2013. Avaliação da sobrevivência de Bradyrhizobium spp em sementes de soja tratadas com fungicidas, protetor celular e inoculante. Revista Internacional de Ciências, 3(1), 43-51. DOI: 10.12957/ric.2013.7063.

Mohiddin, F.A., Khan, M.R., 2013. Tolerance of fungal and bacterial biocontrol agents to six pesticides commonly used in the control of soil borne plant pathogens. African Journal of Agricultural Research, 8(43), 5331-5334. DOI: 10.5897/AJAR11.677.

Palazzini, J.M., Torres, A.M., Chulze, S.N., 2018. Tolerance of triazole-based fungicides by biocontrol agents used to control Fusarium head blight in wheat in Argentina. Letters in Applied Microbiology, 66(5), 434- 438. DOI: 10.1111/lam.12869.

Panhwar, Q.A., Othman, R., Rahman, Z.A., Meon, S., Ismail, M.R., 2012. Isolation and characterization of phosphatesolubilizing bacteria from aerobic rice. African Journal of Biotechnology, 11(11), 2711-2719. DOI: 10.5897/AJB10.2218.

Pereira, C.E., Oliveira, J.A., Caldeira, C.M., Botelho, F.J.E., 2010. Efeito do tratamento das sementes de soja com fungicidas e período de armazenamento na resposta da planta inoculada 
com Bradyrhizobium. Revista Agro@mbiente, 4(2), 62-66. DOI: 10.18227/1982-8470ragro.v4i2.362.

Qiao, J-Q., Wu, H-J., Huo, R., Gao, X-W, Borriss, R., 2014. Stimulation of plant growth and biocontrol by Bacillus amyloliquefaciens subsp. plantarum FZB42 engineered for improved action. Chemical and Biological Technologies in Agriculture, 1(12), 1-14. DOI: 10.1186/s40538-014-0012-2.

Rossi-Zalaf, L.S., Alves, S.B., Lopes, R.B., Silveira Neto, S., Tanzini, M.R., 2008. Interação de micro-organismo com outros agentes de controle de pragas e doenças, in: Alves, S.B., Lopes, R.B., (Ed.). Controle microbiano de pragas na América Latina: avanços e desafios. FEALQ, Piracicaba, p. 279-302.

Saharan, B.S., Nehra, V., 2011. Plant Growth Promoting Rhizobacteria: A critical review. Life Sciences and Medicine Research, 21, 1-30.

Santos, M.M., Rocha, W.S., Silva Júnior, F.R., Chagas Júnior, A.F., Lopes, R.R., 2018. Compatibilidade de tratamentos de sementes e rizóbio, in vitro e em casa de vegetação, no feijãocaupi. Revista Tecnologia \& Ciência Agropecuária, 12(1), 1521.
Sendhilvel, V., Marimuthu, T., Raguchander, T., 2004. Compatibility of azoxystrobin $25 \mathrm{SC}$ with biocontrol agents. Pestology, 28(10), 61-64.

Silva, E.R.L., Alves, L.F.A., Sene, L., Santos, J., Bonini, A.K., Potrich, M., Neves, P.M.O.J., 2006. Técnicas para avaliação do efeito "in vitro" de fungicidas sobre Bacillus thuringiensis var. Kurstaki. Arquivos do Instituto Biológico, 73(4), 429-437.

Sousa, J.A.J., Olivares, F.L., 2016. Plant growth promotion by Streptomycetes: ecophysiology, mechanisms and applications. Chemical Biological Technologies Agriculture, 3(24). DOI: 10.1186/s40538-016-0073-5.

Souza, R., Ambrosini, A., Passaglia, L.M.P., 2015. Plant growth-promoting bacteria as inoculants in agricultural soils. Genetics and Molecular Biology, 38(4), 401-419. DOI: 10.1590/S1415-475738420150053.

Valarmathi, P., Pareek, S.K., Priya, V., Rabindran, R., Chandrasekar, G., 2013. Compatibility of Copper hydroxide (Kocide 3000) with biocontrol agents. IOSR Journal of Agriculture and Veterinary Science, 3(6), 28-31. 